\title{
Design global, manufacture local: Exploring the contours of an emerging productive model
}

\author{
Vasilis Kostakis $^{\mathrm{a}, \mathrm{b}}$, Vasilis Niaros ${ }^{\mathrm{a}, \mathrm{b}, *}$, George Dafermos ${ }^{\mathrm{c}}$, Michel Bauwens ${ }^{\mathrm{d}}$ \\ ${ }^{a}$ Ragnar Nurkse School of Innovation and Governance, Tallinn University of Technology, Akadeemia Street 3, 12618 Tallinn, Estonia \\ ${ }^{\mathrm{b}}$ P2P Lab, Kougkiou 3A, 45221 Ioannina, Greece \\ ${ }^{\mathrm{c}}$ National Institute of Higher Studies (IAEN), Av Rio Amazonas N37 -. 271 y Villalengua, Quito, Ecuador \\ d P2P Foundation, Realengracht 196, 1013AV Amsterdam, The Netherlands
}

\section{A R T I C L E I N F O}

\section{Article history:}

Received 16 February 2015

Received in revised form 30 August 2015

Accepted 1 September 2015

Available online 3 September 2015

\section{Keywords:}

Commons

Peer production

Resilient communities

Degrowth

Desktop manufacturing

3D Printing

\begin{abstract}
A B S T R A C T
This article aims to contribute to the ongoing dialogue on post-capitalist construction by exploring the contours of a commons-oriented productive model. On the basis of this model called "design global-manufacture local", we argue that recent techno-economic developments around the emergence of commons-based peer production and desktop manufacturing technologies, may signal new alternative paths of social organization. We conclude by arguing that all commons-oriented narratives could converge, thereby supporting the creative communities which are building the world they want within the confines of the political economy they aspire to transcend.
\end{abstract}

(c) 2015 Elsevier Ltd. All rights reserved.

\section{Introduction}

The aim of this article is to contribute to the ongoing discussion about post-capitalist construction, and to tentatively propose, from a techno-economic perspective, how a global commons-oriented productive model could be possible. Through the aforementioned model called "design global-manufacture local" (DG-ML), we argue that the emergence of the commons-based peer production signals new alternative paths of social organization. We attempt to show how the DG-ML model, which has been enabled by the conjunction of the modern information and communication technologies (ICT) with the desktop manufacturing technologies (such as the three-dimensional (3D) printing and the computer-numerical-control machines), can offer a sustainable working alternative. Therefore, the current analysis might be a useful techno-social contribution to the research agenda of future studies.

Section 2 deals with the resilient communities approach in relation to degrowth. In short, we discuss the fetishization of localism while we claim that the ultimate goal should be to develop global-oriented productive models. We do not attempt to offer an all-inclusive account but rather to focus on the points where the DG-ML model and framework can be of value. Section 3 includes a description of the basic dynamics that gave rise to a third modality of information production, what Benkler (2006) first called commons-based peer production. It also provides a brief overview of the political economy of the global information commons which determines, as we see in Section 4, the techno-economic conditions from which the DGML productive model is emerging. There, we also refer to three prominent cases which exemplify seed forms of the DG-ML.

\footnotetext{
* Corresponding author at: Tallinn University of Technology, Akadeemia Street 3, 12618 Tallinn, Estonia.

E-mail address: vasileios.niaros@ttu.ee (V. Niaros).
} 
Next, Section 5 addresses the relation of the DG-ML model and degrowth with the criticism of the resilient communities movement, highlighting their complementarity. Moreover, it sheds light on a tentative theoretical model of the DG-ML process introducing a new agenda for action research by future studies scholars, political ecologists, policy makers and practitioners. In Section 6, we conclude arguing that all the commons-oriented narratives could converge and, thus, support the creative communities who are building the world they want, within the confines of the political economy they aspire to transcend.

\section{Degrowth and resilient communities discourses}

The crisis the world is facing, which is not only ecological but also economic, social, cultural and political in nature, has been the point of departure for both degrowth and resilient communities movements. Focusing on strategies for combating the crisis, it has been argued that a radical shift has to take place from growth as the main objective of the economy toward contraction and equitable downscaling (Fournier, 2008; Schneider, Kallis, \& Martinez-Alier, 2010; Foster, 2011; Kallis, Demaria, \& D'Alisa, 2014). Specifically, a transition to a low-carbon, sustainable economy of sharing has been advocated, in which the goal of growth is displaced by the values of social justice and the ethics of collaboration, thus liberating humanity from the yoke of "economism” (Cattaneo, D’Alisa, Kallis, \& Zografos, 2012; Garcia, 2012; Lewis \& Conaty, 2012). This discourse has given rise to new intellectual movements and inspired a revival of radical Green thought (Kallis et al., 2014). Moreover, it has been the catalyst for the creation of numerous eco-communities and eco-villages/urban villages around the world (for a critical discussion of the concept, see Xue, 2014), providing them with the necessary theoretical bedrock.

Indicative of this wave is the Transition Towns movement. The goal of such initiatives is the radical relocalization of politics, economics and culture to autonomous and self-sufficient communities with a view to building resilience against destabilizing forces such as peak oil and climate change. Hopkins - who, in 2006, created a working model of a Transition Town community in Totnes, UK - first introduced this concept in his 2008 book "The Transition Handbook". Nowadays, there are over a hundred transition communities around the world in various stages of development (Chamberlin, 2009; Hopkins, 2011). Despite their individual differences, all of these communities are characterized by their small size, which is intended to ensure that all community members have a strong personal influence over collective decisions (Hopkins, 2008, 2011). The Transition Towns concept is animated by the principles of permaculture, combined with resilience and relocalization. Permaculture, a term which stands for "permanent agriculture", is the design and maintenance of agricultural ecosystems with the diversity, stability, and resilience of natural ecosystems (Mollison, 1988). It is argued that a system based on the permaculture principles can evolve, self-organize and adapt to almost any change (Alexandra \& Riddington, 2007; Meadows, 2008).

Hence, the argument is that in order to counter the volatility and fragility of the dominant system, building resilience locally is fundamental (Latouche, 2009; Lewis \& Conaty, 2012; Trainer, 2012). It is vital to shift to a system with the capacity "to evolve without losing its core sense of identity or purpose" (Wilding, 2011, p. 19). Therefore, resilience can be seen as the degree to which the system is capable of learning, self-organizing and adapting while preserving its coherence (Carpenter, Walker, Anderies, \& Abel, 2001; Folke, 2006; Walker, Abel, Anderies, \& Ryan, 2009). Walker and Salt (2006) along with Lewis and Conaty (2012) highlight some key aspects of resilience: diversity, modularity, reciprocity, social capital (that is, relations of trust and solidarity among community members) and tight feedback loops. Steps and policies towards the world envisioned by resilient communities include the support of a dynamic local economy; the empowerment of local governance and control; the optimization of assets; the recognition of the value of local distinctiveness and of permaculture; the development of sustainable infrastructures (such as, for example, affordable housing, interest-free banks, community land trusts, and autonomous energy production); and the construction of a social solidarity economy (García-Olivares \& Solé, 2015; Lewis \& Conaty, 2012; Wilding, 2011).

According to Xue (2014, p. 131) the local focus of degrowth and resilient communities narratives is evident: "'relocalize' is considered one of the most important approaches and assumes a strategic role". "The idea of relocalization", she continues, "is not confined to economic relocalization though it is an important aspect, but also means political and ecological relocalization." It might be true that relocalization features strongly in early degrowth literature. However, today many of the key degrowth theorists examine more carefully the relationship between the local, the national and the global, and point to the need for political movements as well as institutional change at higher levels than the local (see Kallis, 2011; Kallis et al., 2014; Demaria, Schneider, Sekulova, \& Martinez-Alier, 2013; who emphasize the multi-scale degrowth strategy).

In its most extreme form, the resilient community approach may include lifeboat strategies and initiatives for the protection of small communities amidst generalized chaos. This may build on the idea that we must accept the reality of considerably more expensive energy and food (Lewis \& Conaty, 2012). What characterizes this discourse is the rejection of the value of bigness and an opposition to the organizational tendency toward large scale. Even though relations of collaboration and solidarity may well extend to the global level, the focus remains firmly on the local. Most often, political and social mobilization on a large scale is seen as unrealistic and doomed to failure. Resilience and vulnerability are not often used in the modern degrowth literature which is against a pure survivalist spirit (Kallis, 2014). As Kallis (2014) stresses, "a 'survivalist' take on degrowth . . . hides the fact that we are not all equally responsible or equally vulnerable ... . [and] opens the potential for authoritarian responses to save 'us' from disaster”. In contrast to Romano's (2012, p. 582) idea that degrowth just offers “techniques that will allow the human species merely to 'stay alive”, Kallis et al. (2014, p. 9) write against an 
“apolitical, technocratic discourse of sustainable development” and set the scene for an alternative political vision, where “'sharing', 'simplicity', 'conviviality', 'care' and the 'commons' are primary significations of what this society might look like” (p. 3).

The development of resilient communities, which are squarely aimed at generating community value, is without a doubt a healthy reaction against global problems and environmental degradation. Resilient communities try to be immune to the dominant system and use peer-to-peer practices and technologies for good reasons (for example, the Transition Towns concept incorporates open source organizational practices). They try to support individuals's physical and psychological well-being by creating a positive sense of place, by localizing the economy within ecological limits, and by ensuring the entrepreneurial/community stewardship of the local commons (Wilding, 2011). They do not, however, build global structures. In our view, these structures are essential: organizing an ecumenical counter-power that is able to propose alternative models of social organization on a global scale is of paramount importance. For Sharzer (2012), localism is a type of fetishization of (small) scale, as some positive benefit is ascribed to a place precisely because it is small. He argues that communities driven by that ideal are inevitably assimilated by the broader capitalist economy, because they do not confront it, but rather try to avoid it. Initiatives like Transition Towns are gaining momentum in the context of efforts focusing on the local level. As we will point out below however, they can co-exist in harmony with the approach of the global commons. This is based on the rationale that whatever is heavy is local (for instance, desktop manufacturing technologies), and whatever is light is global (for instance, global knowledge commons).

Arguably the real issue is not how to produce and consume less, but how to develop new productive models which are capable of outperforming capitalist models, i.e., by doing things differently and better. We consider it impossible to challenge the dominant system without a working plan to transcend it. Transitioning to a post-capitalist world goes well beyond the mere regression to pre-industrial times. Echoing Fuster Morell (2014, p. 160), there are several commonalities between the digital commons and the concept of degrowth, which calls for a transition to a future of frugal innovations. We will thus attempt to discuss about new institutions, fueled by the spirit of the global commons, with the aim of providing a viable alternative based on integral perspectives, theories and narratives.

\section{A new mode of information production: commons-based peer production}

Plenty of attention has been gathering around the commons. But what is its concept all about? In general it is a term that refers to shared resources where each stakeholder has an equal interest (Ostrom, 1990). The commons sphere can include natural gifts such as air, water, the oceans and wildlife, and shared "assets" or creative work like the Internet, the airwaves, the languages, our cultural heritage and public knowledge which have been accumulating since time immemorial (Bollier, 2005, 2009). Also, the commons might simultaneously refer to shared resources, a discourse, a new/old property framework, social processes and relations, or an ethic (Bollier, 2014).

During the last two decades, several commons-based projects such as myriad of free/open source software projects or the free encyclopedia Wikipedia have highlighted "the emergence of technological capabilities shaped by human factors, which in turn shape the environment under which humans live and work" (Kostakis \& Bauwens, 2014, p. 51). They create what Benkler (2006, p. 31) calls new "technological-economic feasibility spaces" for social practice. These feasibility spaces contain "different social and economic arrangements, where profit, power, and control do not seem as predominant as they have in the history of modern capitalism" (Kostakis \& Bauwens, 2014, p. 51).

Commons-based peer production is a new collaborative and distributed form of organization emerging from this new interconnected digital and physical environment. When it comes to information, peer production is more productive than market-based or centrally-controlled systems (Benkler, 2006). It produces social well-being because it is based on people's intrinsic positive motivations and synergetic cooperation among participants and users (Benkler, 2006; Hertel, Niedner, \& Herrmann, 2003; Lakhani \& Wolf, 2005). According to a study of the incentives of 141 Linux kernel community participants, the former were driven "by similar motives as voluntary action within social movements such as the civil rights movement, the labor movement, or the peace movement" (Hertel et al., 2003, p. 1174).

Benkler (2006) makes two intriguing economic observations which challenge some "eternal truths" of the mainstream economic theory. Commons-based projects fundamentally challenge the assumption that in economic production, the human being solely seeks profit maximization. Volunteers contribute to information production projects, while they gain knowledge, experience, and reputation, and communicate with each other motivated by intrinsically positive incentives. This does not mean that the monetary motive is totally absent; however, it is relegated to a peripheral concept (Benkler, 2006).

The second challenge is directed against the conventional wisdom that, in Benkler's (2006, p. 463) words, “we have only two basic free transactional forms-property-based markets and hierarchically organized firms". In contrast to markets, in peer production the allocation of resources is not done through a market-pricing mechanism. Hybrid modes of governance are employed and what is generated is not commodities, but a commons. Peer production is opposed to industrial firms's hierarchical control and authority as it is based on communal validation and negotiated coordination with a communitydriven quality control (see, for instance, Dafermos's (2012) study on the Free BSD project's collectivist and consensusoriented governance system).

Instead of the division of labor, a distribution of modular tasks takes place with anyone able to contribute to any module and the threshold for participation as low as possible: modularity is vital for peer production to emerge (Bauwens, 2005; 
Tapscott \& Williams, 2006; Kostakis \& Papachristou, 2014). Described in technical terms, modularity is a form of task decomposition. It is used to separate the work of different groups of developers, creating, in effect, related yet separate subprojects (Dafermos \& Söderberg, 2009). Torvalds (1999), the instigator of the Linux project, maintains that the Linux kernel development model requires modularity, because in that way, people can work in parallel. Empirical research shows that modular design is characteristic not just of Linux but of the free/open source software development model in general (MacCormack, Rusnak, \& Baldwin, 2007).

Further, modularity leads to stigmergic collaboration. In its most generic formulation, stigmergy is the phenomenon of indirect communication among agents and actions (Marsh \& Onof, 2007, p. 1). An action leaves a trace which stimulates the performance of a next action, by the same or a different agent. Therefore, in the context of peer production, stigmergic collaboration is the "collective, distributed action in which social negotiation is stigmergically mediated by Internet-based technologies” (Elliott, 2006). For example, see how free/open source software and Wikipedia entries are being produced in a distributed and ad hoc fashion through the contributions from large numbers of people.

Moreover, peer production is opposed to the notion of scarcity of goods through which market profit is generated, as the practice of sharing the created goods does not diminish their value, but actually enhances it (Benkler, 2006). To this, one might add that peer production is facilitated by the free cooperation of creative communities, which lowers the legal restrictive barriers and invents new institutionalized ways of sharing, such as the Creative Commons or the General Public Licenses (Kostakis, Fountouklis, \& Drechsler, 2013). It is, however, important to highlight that contributors to peer production projects do have interests and rights concerning their work and are interested in protecting their intellectual property (O'Mahony, 2003). Thus, the commons-oriented approach to property "does not assert that sharing is an ethical absolute", but rather tries to balance the rights of innovators with the rights of the public (O’Mahony, 2003; von Hippel \& von Krogh, 2003).

It becomes obvious that what sets peer production apart from proprietary models of production are three key characteristics: (a) the decentralization of the conception of problems and the execution of solutions; (b) the diversity of participants's motivations; and (c) the decoupling of governance from private property and contract (Benkler, 2015). These characteristics make peer production agile enough to adapt to complex environments (Benkler, 2015) and provide the capacity to deliver innovative results such as the Apache web server, Mozilla Firefox browser, Linux kernel, BIND, Sendmail, and a myriad of emerging open source hardware projects.

Beyond the great potential of peer production, there might be various obstacles, practical problems and negative side effects (Kostakis et al., 2013). However, taken in this idealized context, peer production is arguably a carrier of forces which create a political economy where economic efficiency, profit, and competitiveness cease to be the sole guiding stars (Moore \& Karatzogianni, 2009), while civil society attains a more important role, bringing (back) the notion of the commons into the heart of the economy (Orsi, 2009). From this point of view, the commons can be seen as a legitimate vehicle of citizenship or as an equivalent of Tocqueville's (2010) civil society, through which citizens mobilize and express their interests while protecting their rights (MacKinnon, 2012). It can be central to the process of civilizing the economy, which would require a strong notion of citizenship-of membership in a global civil society (Brown, 2010).

The commons movement is arguably removing property relations as our political economy's foundation and is replacing them with civic relations that define our bonds with each other (Brown, 2010; Kostakis \& Bauwens, 2014, p. 55). The commons are long-term social and material processes that cannot be created overnight: "in order to become meaningful they must exist over an extensive period of time" (Stadler, 2014, p. 31). In other words, the various spheres of the commons are products of peer-to-peer creative processes as they expand horizontally and in dense interconnections with each other. That is why we must go beyond a material understanding of the concept and approach the commons not only as a resource or as a property regime, but rather as a social process. Producing a categorization or taxonomy of the commons based on what type of resource is involved can be misleading, as Bollier (2014) warns us:

While choosing to categorize commons by the type of resource involved is tempting, a focus on the resource alone can be misleading. For example, a "knowledge commons" on the Internet is not simply about intangible resources such as software code or digital files; such a commons also requires physical resources to function (computers, electricity, food for human beings). By the same token, "natural resource commons" are not just about timber or fish or corn, because these resources, like all commons, can only be managed through social relationships and shared knowledge.

In other words, to quote Helfrich (2013), "all commons are social, and all commons are knowledge commons". Our relationships to shared goods that are managed as commons should be the focal point and, thus, we should discuss the process of commoning (i.e., do things in common).

But what alternative productive models should we experiment with in order to build sustainable, commons-oriented economies and societies? Section 4 points to three commons-based projects that share certain characteristics that could inaugurate a new proto-mode of material production, as explained in Section 5.

\section{Seeds of a new mode of material production: commons-based peer production and desktop manufacturing}

Contrary to the conventional industrial paradigm and its economies of scale, peer production and desktop manufacturing could arguably develop commons-based economies of scope. While the advantages of scale rest on high-capital-entry and cheap global transportation, which is facing problems due to the environmental crisis, the commons-based economies of scope share infrastructure costs in terms of intangible and tangible productive resources. They utilize the capabilities of the new fabrication tools which, up to a degree, are computerizing the manufacturing industry (Hermann, Pentek, \& Otto, 2015). 
There is a growing tendency for the creation of a new type of communities, which follow a global commons approach that focuses on a larger scale in relation to the resilient communities. Advocates and participants of those communities argue that the commons should be created and fought for on a transnational global scale (Kostakis \& Bauwens, 2014).

The RepRap project, the Open Source Ecology and the Wikispeed car are prominent cases that build on the convergence of global commons with desktop manufacturing technologies. We consider them as seeds of an emerging mode of material production, called DG-ML. Hence, it is arguably of great importance to pinpoint the necessary conditions that will allow us to draw several proposals for a new action research agenda for political ecologists, policy makers, practitioners and future studies scholars.

To begin with, the RepRap was introduced by Adrian Bowyer in 2005. His goal was to create a 3D printer that could selfreplicate by manufacturing its main components. This project was conceived as a peer production artifact, meaning that the technical specifications and its design files are open source. This has resulted in the formulation of networks of individuals which offered significant incremental innovations to the original design. Three updated versions of the RepRap were released in the years that followed. By 2010 the RepRap had a 5000-strong community which has rapidly been expanding (de Bruijn, 2010).

Further, the Open Source Ecology is an open hardware project focused on manufacturing a set of fifty industrial machines, called the "Global Village Construction Set", which it considers to be sufficient for creating a small civilization with modern comforts from locally available resources. The development of the machines is distributed across a global network of parsimoniously linked, self-managing groups of hardware hackers and hobbyists who share design information through the Internet and build prototypes, which are then tested in a farm in Missouri, USA. So, as a start, Marcin Jakubowski, a Missouribased physicist, designed a new tractor and posted the design on the Internet under a commons-based license. This attracted the attention of the Internet community and of hardware hackers and hobbyists around the world, who soon started to contribute improvements and build prototypes. And thus, the Open Source Ecology network was born in 2003 . With the help of this network of contributors, Jakubowski identified the fifty machines - from cement mixers to 3D printers and moving vehicles - which are necessary to build a sustainable modern village community and embarked on a collective effort to manufacture them. To accommodate the enlarged scope of work, the project was officially launched as a platform for coordinating the enterprise and Jakubowski's farm was repurposed into a site for building and testing the prototypes developed by project members from all over the world, many of whom would come to the farm on "dedicated project visits" to help with the work (Thomson \& Jakubowski 2012, pp. 53-70).

To date, of the fifty machines that make up the Global Village Construction Set, eight have already been successfully manufactured, while development of the rest is currently underway. By tapping into the contributions of a global community of hardware hackers and afficionados, this project has achieved significant cost reductions (Dafermos, 2015). To its credit, the machines built by Open Source Ecology have a much lower cost of production than their industrial counterparts, being at least eight times cheaper to manufacture (Dafermos, 2015).

Although community contributions raised through crowdfunding campaigns have so far been Open Source Ecology's main source of financial support (Jakubowski, 2011), the aforementioned production cost savings allow the project to finance its activities by selling its machines directly to farmers. Indicatively, it estimates to make about $\$ 80 \mathrm{~K}$ a month by selling its tractors at a price of $\$ 10 \mathrm{~K}$ (Jakubowski, 2013). Also, additional revenue comes from the educational courses and workshops that Open Source Ecology offers to people who are interested in learning how to build their own machines.

However, the sustainability of the Open Source Ecology enterprise extends well beyond its business model: this project furnishes a working example of how farming and the manufacturing of agricultural machines can be carried out in a way that is not only productive but also environmentally sustainable (Dafermos, 2015). For example, the electricity that Jakubowski's farm consumes, which includes a 4000 square foot fabrication facility and a 3000 square feet living unit, comes from renewable energy resources, using methods like closed-loop manufacturing (which recycle waste materials into livestock for other production processes; for a detailed discussion, see Kelly 1994, ch. 10) and technologies that the project itself has built such as photovoltaic panels and wind turbines (Open Source Ecology, 2013). Equally important, Open Source Ecologymanufactured machines are designed with the principle of durability in mind and in such a way as to be easily repairable and modifiable by end-users (Dafermos, 2015). In that regard, the Open Source Ecology machines are paradigmatic of what is called sustainable design: they are designed to last for a lifetime, rather than throw away and replace by newer machines.

Our last case is the development process of the Wikispeed car. What makes this process unique is that fact that it is driven by a global community of volunteers who, through peer production methods, are able to manufacture cars at highly reduced time and cost compared to conventional ones. A network of semi-autonomous teams with their own garage are the main developers. Their shared activities, which are coordinated online, are made possible by the modular structure of the car. This means that individual modules of the car may be developed autonomously with minimal central coordination.

The Wikispeed car embodies the basic characteristic of peer production: all knowledge regarding its development (design, specifications) is available to the community so that everyone may be able to contribute, thus benefiting from the assistance of volunteers from around the world. Free access to information enables the core team of the project to establish a collective model of development for the car, and at the same time set the foundation for a distributed entrepreneurship model were individuals may download and utilize all the available information to develop their own car.

To sum up, the above cases as open source projects utilize the globally designed commons to assist the formulation of global communities. They basically illustrate how commons-based technology along with desktop manufacturing can provide more autonomy while at the same time transforming the productive sectors's economic and environmental aspects 
(Dafermos, 2015). In essence, they imagine a novel production model that is suitable for a post-fossil fuel economy. A model whose basic principles are decentralization, resilience, smallness, on demand and locally controlled production, and most importantly global development.

\section{Towards a new productive model: design global, manufacture local}

The resulting distributed organizational infrastructures of the cases discussed in the previous section is arguably key to realizing significant economies of scope and flexibility. The sustainability implications of such a paradigm shift in manufacturing are arguably obvious: we see the emergence of DG-ML productive model which leverages the global design commons for local manufacturing. As said in Section 4, unlike large-scale industrial manufacturing, the DG-ML model emphasizes application that is small-scale, decentralized, resilient and locally controlled.

In other words, a model of sustainable development which recognizes the limits to growth posed by finite resources and organizes material activities accordingly. From an environmental perspective, a useful way to see this emerging productive model is through a "stack" of interlocked practices that create a positive feedback loop:

- Design for sustainability. Proprietary design in for-profit enterprises often aims to achieve planned obsolescence to maintain tension between supply and demand. Commons-oriented design communities do not have the same incentives and "generically" design for sustainability, modularity, and participatory design. This design is open and transparently available and usable by other designers, citizens and entrepreneurs, and guarantees that the rapid innovation is available everywhere.

- Distributed machinery. The second practice involves the use of desktop manufacturing technologies to create a demanddriven production system, instead of a supply-driven system, and allows relocalization of manufacturing.

- Mutualisation. The third practice is related to the mutualization of the products of industry itself, i.e., the genuine "sharing economy" in which idle resources are identified and used in mutual ways.

- Commons-oriented property regimes. The fourth practice includes adapted models of ownership and governance which facilitate generative forms for the management of productive resources.

Elements of all these practices have emerged and are present in fragmented ways, but have not yet been integrated into an organic mode of production and distribution of value. So, how could such a model be scaled-up? Are there any hints on the role of the state and the market? We attempt to provide a tentative description of such a theoretical model that builds on the convergence of the degrowth and peer production narratives, the resilient communities and the lessons taught by the emerging DG-ML projects that utilize both ICT and desktop manufacturing technologies. To do so, the following figure would help us in outlining our proposal (Fig. 1).

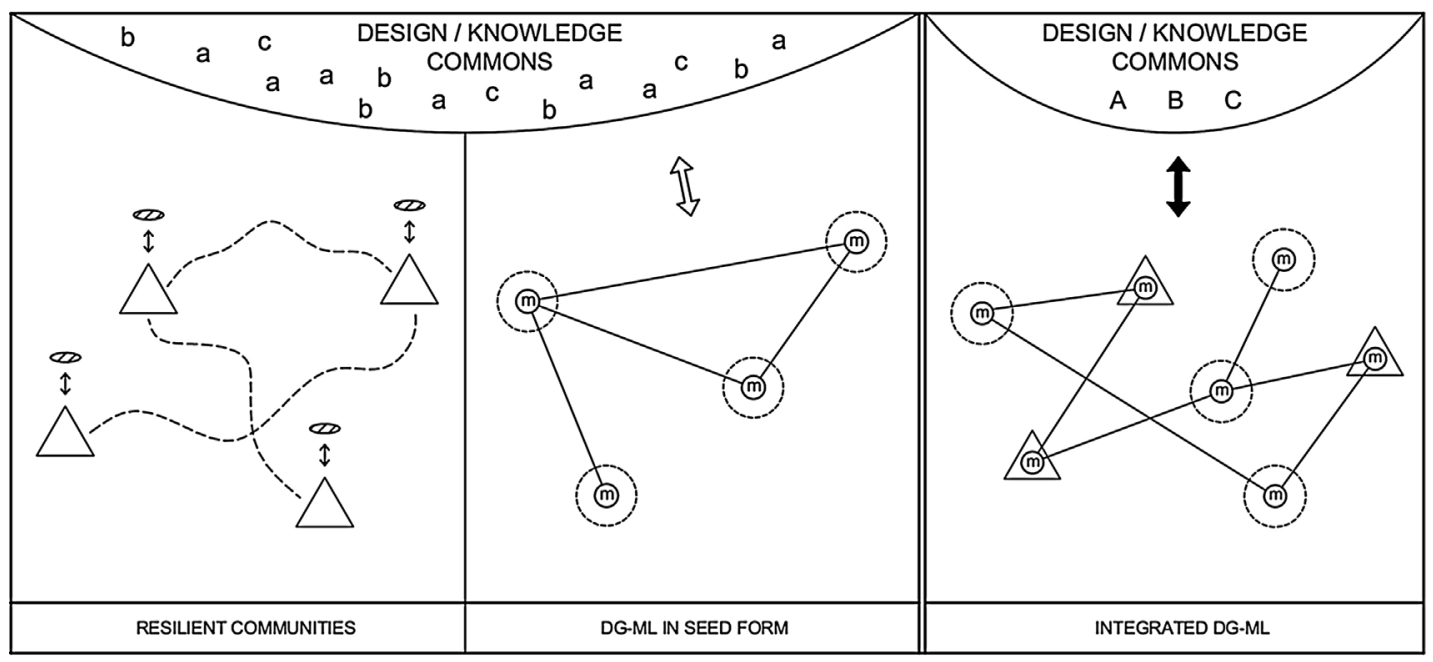

\begin{tabular}{|lll|}
\hline$:$ Resilient community / Eco-village & O : Community utilizing the DG-ML model & ${ }_{c}^{\mathrm{a}} \mathrm{b}:$ Scattered knowledge commons \\
$\infty:$ Local knowledge commons & $\mathrm{m}:$ Micro-factory / Makerspace & A Bc : Aggregated knowledge commons \\
\hline
\end{tabular}

Fig. 1. A proposal for convergence: the DG-ML productive model.

1 It should be noted that the theoretical framework provided in Section 3 is a reworked excerpt from the Kostakis et al., 2013 and the Kostakis \& Bauwens, 2014. 
The main vein of our critique to resilient communities, as stated in Section 2, is twofold. First, many resilient communities and eco-villages are producing a design/knowledge commons while working to meet their needs, but because of their local focus: they have loose connections with each other; they do not produce a global commons; and thus they fail to contribute to the formation of a global counter-power. Second, a radical shift should take place toward contraction and downscaling, whereas we claim that there are possibilities for "doing things differently" utilizing the modern community-driven technologies and practices. In line with degrowth and resilient communities narratives, we are arguably living the endgame of neoliberal material globalization based on cheap energy, which necessitates relocalization of production. However, we have new possibilities for online, affinity-based socialization, coupled with the resulting physical interactions and community building. The value-creation communities of the global commons approach might be locally based but are globally linked. Out of that, there may come new forms of business organization, which are substantially more communityoriented. This approach sees no contradiction between global open design collaboration, and local production/ manufacturing: both can occur simultaneously, so the relocalized reterritorialization will be accompanied by global networks of enterprises. The various information commons, based on shared knowledge, code and design, will be part of these new global knowledge networks, but closely linked to relocalized implementations.

It is obvious that the emergence of the community-driven development model characteristic of Wikispeed, Open Source Ecology and RepRap would have been impossible in the absence of the design/knowledge commons and the respective digital platforms of each project. So, at the most basic level, the scaling up of the DG-ML model would firstly require distributed access to enabling collaborative socio-technological digital platforms that would allow knowledge workers, farmers, hackers, engineers, scientists, hobbyists and open design communities to collaborate on joint or individual projects on a global basis. In a nutshell, it would include the state of the art of open source hardware, i.e., a stack of essential technologies in relation to each productive realm. The knowledge should be documented step-by-step in several languages, so that almost anybody may understand how a certain solution is implemented, replicated or even advanced. Moreover, it would be important to develop open assessment systems so that everyone could contribute to maturity evaluations of the projects. So, the current platforms and libraries of global design/knowledge commons should become more accessible and user-friendly. A proposal could be that the state organizes this first layer of infrastructure enriched with the design/ knowledge commons produced by the universities and other research institutes which are funded by tax payers money. Further, the legal framework of the digital commons, especially concerning the open hardware, should be advanced, maybe in line with the proposal for commons-based reciprocal licenses (Bauwens \& Kostakis, 2014).

Secondly, the scaling up of the DG-ML model would require distributed access to fixed capital, i.e., a spectrum of hardware technologies such as personal computers and desktop manufacturing technologies, which constitute the essential means of production in this setting. Though production is distributed and therefore facilitated at the local level, the conjunction of peer production practices and products with desktop manufacturing technologies could create sustainable business ecologies. There, the resulting micro-factories/makerspaces, essentially networked on a global scale, would profit from mutualized global cooperation, both on the design of the product and on the improvement of common machinery. "Microfactories" is a concept that refers to small dimension, automated factories capable of greatly conserving resources like space, energy, materials and time (Okazaki, Mishima, \& Ashida, 2004; Tanaka, 2001). They are likely to feature automatic machine tools, assembly systems, evaluation and control systems, a quality inspection system and waste elimination system (Koch, 2010; Kussul et al., 2002). Micro-factories can be identical to makerspaces/fablabs which can be found either in hackerspaces, media labs, and other co-working or community-driven spaces (Troxler, 2011). Community-driven microfactories are commonly used by individuals and groups with limited financial resources as a local, physical platform for the mutualization of resources and the provision of shared access to those means of production that are not yet as distributed and generally available as personal computers and Internet connectivity. As such, they form a territorial infrastructure for the development of commons-oriented projects like RepRap and Wikispeed. Again, on the regional, national and international level, a proposal could be that the state empowers, supports and even builds micro-factories/makerspaces and intellectual hubs so that bottom-up modes of collaboration and entrepreneurship, which would build on the commons, are developed.

Any distributed enterprise could be seen in the context of transnational alliances of ethical enterprises that operate in solidarity around a particular knowledge commons (de Ugarte, 2014; P2P Foundation, 2014). As the key terrain of conflict is around the relative autonomy of the commons vis-a-vis for-profit companies, we are in favor of a preferential choice towards entrepreneurial formats which integrate the value system of the commons, rather than profit-maximization. In this context, the creation of businesses by the community, can make the commons viable and sustainable over the long run. Advocates of this scenario struggle for a shift from the current flock of community-oriented businesses towards business-enhanced communities. They believe that we need corporate entities which are sustainable from the inside out, not just via external regulation from the state, but from their own internal statutes and links to commons-oriented value systems.

Hence, the third layer relates to the local communities and the development of entrepreneurial coalitions and relevant funding ecologies. Through local hubs (private and public) and the development of a global network of micro-factories/ makerspaces and commons-oriented communities, various entrepreneurial coalitions (often in the form of co-operatives) could be catalyzed. The goal should be the creation of a funding infrastructure that benefits and sustains the design/ knowledge commons, creates added value on top, and markets these as products or services. Public authorities and governments could help orchestrate the public-private-commons triad in order to benefit from the local effects of the new networked "coopetition" between entrepreneurial coalitions and their linked communities. 
Therefore, political and social mobilization on the regional, national and transnational scale is seen as part of the struggle for the transformation of institutions. Participating enterprises are vehicles for the commoners to sustain global commons as well as their own livelihoods. This approach does not take social regression as a given, and believes in frugal abundance for the whole of humanity. It envisions a transition to a paradigm which would include new decentralized and distributed systems of provisioning and democratic governance, escaping the pathologies of the current political economy and constructing an ecologically sustainable alternative (Bollier, 2014). To achieve such a transition, the global commons scenario, through the DG-ML productive model, suggests that we should work on building both global and local political and social infrastructures. Of course, we do not argue that peer production can instantly substitute all production processes or that centralized infrastructures (such as water supply) are useless. Peer production is a proto-mode of production and, thus, currently unable to perpetuate itself on its own outside capitalism, to an autonomous and real mode of production. It has been argued (Kostakis \& Bauwens, 2014) that the state could catalyze such a transition to hybrid modes of production reconfiguring the micro-economic and macro-economic level in the spirit of certain commons-oriented policies. Central to this discussion are the concepts of the "ethical market", which would include commons-oriented enterprises, as well as the "partner state", which would enable and empower direct social-value creation by providing support for the basic infrastructures, and focus on the protection of the commons sphere (Orsi, 2009; Kostakis \& Bauwens, 2014 and for a critical perspective Rigi 2012, 2013, 2014).

\section{Conclusions}

In this paper, we attempted to make a contribution to the discussion on degrowth and resilient communities from a techno-economic perspective. It has been claimed that techno-economic paradigm shifts are never the result of technological forces alone, but also presuppose the creation of new social institutions, of new norms and value systems (Perez, 1983, 2009). Viewed from that perspective, resilient communities, the degrowth movement and peer production are complementary components of a paradigm shift away from an economic system based on the irrational exploitation of natural resources and the ecologically destructive magnification of production and consumption, towards one characterized by a radically different definition of the content of human well-being and happiness.

The model advocated here bears a lot of resemblance and materializes ideals that are core to the degrowth imaginary, such as "autonomy" or "conviviality" (see Kallis et al., 2014 for discussions on the work of Ivan Illich and Andre Gorz in relation to degrowth). Resilient communities provide not only a blueprint for the creation of self-sufficient communities but also a fertile ground for the application and further elaboration of the degrowth movement's strategies and policies for transitioning to a sustainable economy. In the context of this experimentation with alternatives, both resilient communities and the degrowth movement would be well advised to look into the mode of peer production and focus on a larger scale by following a global commons approach. This shift, along with the embrace of desktop manufacturing technologies, will allow the implementation of the DG-ML productive model, which could offer an alternative of how productive activities could be organized during the transition period to a more sustainable post-capitalist society.

Last, of particular interest for future research will be an evidence-based documentation of the sustainability aspects of commons-based peer production's convergence with desktop manufacturing technologies, as well as to advance their integration into a coherent mode of production and value distribution in the vein of degrowth.

\section{Acknowledgments}

The authors would like to express their gratitude to Chris Giotitsas, Alekos Pantazis, Andreas Roos and two anonymous reviewers for their constructive criticism. This work was supported by the "Challenges to State Modernization in 21st Century Europe" Estonian Institutional Grant [IUT 19-13].

\section{References}

Alexandra, J., \& Riddington, C. (2007). Redreaming the rural landscape. Futures, 39(2-3), $324-339$.

Bauwens, M. (2005). The Political Economy of Peer Production. CTheory Journal. http://www.ctheory.net/articles.aspx?id=499 Accessed 1.09.15.

Bauwens, M., \& Kostakis, V. (2014). From the communism of capital to capital for the commons: towards an open co-operativism triple C: communication. Capitalism \& Critique, 12(1), 356-361.

Benkler, Y. (2006). The wealth of networks: how social production transforms markets and freedom. New Haven, CT: Yale University Press.

Benkler, Y. (2015). Peer Production and Cooperation. In J. M. Bauer, \& M. Latzer (Eds.), Handbook on the economics of the internetEdward Elgar.

Bollier, D. (2005). Brand name bullies: the quest to own and control culture. Hoboken, NJ: Wiley.

Bollier, D. (2009). Viral spiral: how the commoners built a digital republic of their own. New York, NY: New Press.

Bollier, D. (2014). The Commons as a Template for Transformation. Great Transition Initiative. http://www.greattransition.org/document/the-commons-asa-template-for-transformation Accessed 1.09.15.

Brown, M. T. (2010). Civilizing the economy: a new economics of provision. Cambridge: Cambridge University Press.

Carpenter, S. R., Walker, B. H., Anderies, J. M., \& Abel, N. (2001). From metaphor to measurement: resilience of what to what? Ecosystems, 4, 765-781.

Cattaneo, C., D’Alisa, G., Kallis, G., \& Zografos, C. (2012). Degrowth futures and democracy. Futures, 44(6), 515-523.

Chamberlin, S. (2009). The transition timeline: for a local, resilient future. Cambridge: Green Books.

Dafermos, G. (2012). Authority in peer production: the emergence of governance in the free BSD project. Journal of Peer Production, 1(1), 1-12.

Dafermos, G. (2015). Transforming the productive base of the economy through the open design commons and distributed manufacturing. Journal of Peer Production, 7, http://peerproduction.net/issues/issue-7-policies-for-the-commons/peer-reviewed-papers/distributed-manufacturing/ Accessed 5.09.15. 
Dafermos, G., \& Söderberg, J. (2009). The hacker movement as a continuation of labour struggle. Capital E' Class, 33, 53-73.

de Bruijn, E. (2010). On the Viability of the Open Source Development Model for the Design of Physical Objects: Lessons Learned from the RepRap Project. (MSc dissertation), Tilburg University. http://thesis.erikdebruijn.nl/master/MScThesis-ErikDeBruijn-2010.pdf Accessed 1.09.15.

de Ugarte, D. (2014). Trilogía de las Redes. http://lasindias.com/de-las-naciones-a-las-redes Accessed 1.09.15.

Demaria, F., Schneider, F., Sekulova, F., \& Martinez-Alier, J. (2013). What is degrowth? from an activist slogan to a social movement. Environmental Values, 22 (2), 191-215.

Elliott, M. (2006). Stigmergic collaboration: the evolution of group work. M/C Journal: A Journal of Media and Culture, 9(2) .

Folke, C. (2006). Resilience: the emergence of a perspective for social-ecological systems analyses. Global Environmental Change, $16,253-267$.

Foster, J.B. (2011). Capitalism and Degrowth: An Impossibility Theorem. Monthly Review, 62(8). https://monthlyreview.org/2011/01/01/capitalism-anddegrowth-an-impossibility-theorem Accessed 1.09.15.

Fournier, V. (2008). Escaping from the economy: the politics of degrowth. International Journal of Sociology and Social Policy, $28(11 / 12), 528-545$.

Fuster Morell, M. (2014). Digital Commons. In G. D'Alisa, F. Demaria, \& G. Kallis (Eds.), Degrowth: a vocabulary for a new era (pp. 159-161). New York, NY: Routledge.

Garcia, E. (2012). Degrowth, the past, the future, and the human nature. Futures, 44(6), 546-552.

García-Olivares, A., \& Solé, J. (2015). End of growth and the structural instability of capitalism: from capitalism to a symbiotic economy. Futures, 68, 31-43.

Helfrich, S. (2013). Economics and the Commons?! Towards a Commons-Creating Peer Economy. Paper presented at the Economics and the Commons Conference, Berlin. http://commonsandeconomics.org/2013/06/09/silke-helfrichs-opening-keynote-towards-a-commons-creating-peer-economy Accessed 1.09.15.

Hermann, M., Pentek, T., \& Otto, B. (2015). Design principles for industrie 4.0 scenarios: a literature review. Dortmund: Technische Universität.

Hertel, G., Niedner, S., \& Herrmann, S. (2003). Motivation of software developers in open source projects: an internet-based survey of contributors to the Linux kernel. Research Policy, 32, 1159-1177.

Hopkins, R. (2008). The transition handbook: from oil dependency to local resilience. Cambridge: Green Books.

Hopkins, R. (2011). The transition companion: making your community more resilient in uncertain times. Cambridge: Green Books.

Jakubowski, M. (2011). Global Village Construction Set Kickstarter Campaign. https://www.kickstarter.com/projects/622508883/global-villageconstruction-set Accessed 1.09.15.

Jakubowski, M. (2013). The Open Source Economy. http://www.marioninstitute.org/videos/2013/marcin-jakubowski-open-source-economy Accessed 1.09.15.

Kallis, G. (2011). In defence of degrowth. Ecological Economics, 70(5), 873-880.

Kallis, G. (2014). Response by Giorgos Kallis to Brian Davey's Review of Degrowth. Feasta. http://www.feasta.org/2014/12/22/response-by-giorgos-kallis-tobrian-daveys-review-of-degrowth/ Accessed 1.09.15.

Kallis, G., Demaria, F., \& D’Alisa, G. (2014). Degrowth. In G. D’Alisa, F. Demaria, \& G. Kallis (Eds.), Degrowth: a vocabulary for a new era (pp. 1-17). New York, NY Routledge.

Kelly, K. (1994). Out of control: the new biology of machines, social systems, and the economic world. Basic Books.

Koch, M.D. (2010). Utilizing Emergent Web-Based Software Tools as an Effective Method for Increasing Collaboration and Knowledge Sharing in Collocated Student Design Teams. (MSc), Oregon State University. http://ir.library.oregonstate.edu/xmlui/handle/1957/16855 Accessed 1.09.15.

Kostakis, V., \& Bauwens, M. (2014). Network society and future scenarios for a collaborative economy. Basingstoke, UK: Palgrave Macmillan.

Kostakis, V., Fountouklis, M., \& Drechsler, W. (2013). Peer production and desktop manufacturing: the case of the Helix_T wind turbine project. Science, Technology E' Human Values, 38(6), 773-800.

Kostakis, V., \& Papachristou, M. (2014). Commons-based peer production and digital fabrication: the case of a reprap-based, lego-built 3D printing-milling machine. Telematics and Informatics, 31(3), 434-443.

Kussul, E., Baidyk, T., Ruiz-Huerta, L., Caballero-Ruiz, A., Velasco, G., \& Kasatkina, L. (2002). Development of micromachine tool prototypes for microfactories. Journal of Micromechanics and Microengineering, 12(6), 795-812.

Lakhani, K., \& Wolf, R. (2005). Why Hackers Do What They Do: Understanding Motivation and effort in free/open source software projects. In J. Feller, B. Fitzgerald, S. Hissam, \& K. Lakhani (Eds.), Perspectives on free and open source software (pp. 3-22). Cambridge, MA: MIT Press.

Latouche, S. (2009). Farewell to growth. Cambridge, MA: Polity.

Lewis, M., \& Conaty, P. (2012). The resilience imperative: cooperative transitions to a steady-state economy. Gabriola Island: New Society Publishers.

MacCormack, A., Rusnak, J., Baldwin, C.Y. (2007). The Impact of Component Modularity on Design Evolution: Evidence from the Software Industry. Harvard Business School Technology \& Operations Mgt. Unit, 08-038. http://ssrn.com/abstract=1071720 Accessed 1..09.15.

MacKinnon, R. (2012). Consent of the networked. New York, NY: Basic Books.

Marsh, L., \& Onof, C. (2007). Stigmergic epistemology, stigmergic cognition. Cognitive Systems Research, 9(1-2), 136-149.

Meadows, D. (2008). Thinking in systems: a primer. Vermont, VT: Chelsea Green Publishing.

Mollison, B. (1988). Permaculture: a designers' manual. Tyalgum: Tagari Publications.

Moore, P., \& Karatzogianni, A. (2009). Parallel visions of peer production. Capital E Class, 33, 7-11.

O'Mahony, S. (2003). Guarding the commons: how community managed software projects protect their work. Research Policy, 32, $1179-1198$.

Okazaki, Y., Mishima, N., \& Ashida, K. (2004). Microfactory-concept, history, and developments. Journal of Manufacturing Science and Engineering, 126(4), 837-844.

Open Source Ecology (2013). Open Source Ecology Shop 2011. http://opensourceecology.org/wiki/OSE_Shop_2011 Accessed 1.09.15.

Orsi, C. (2009). Knowledge-based society, peer production and the common good. Capital E Class, 33, 31-51.

Ostrom, E. (1990). Governing the commons: the evolution of institutions for collective action. Cambridge: Cambridge University Press.

P2P Foundation (2014). Phyles. http://p2pfoundation.net/Phyles Accessed 1.09.15.

Perez, C. (1983). Structural change and assimilation of new technologies in the economic and social systems. Futures, 15(5), 357-375.

Perez, C. (2009). Technological revolutions and techno-economic paradigms. Cambridge Journal of Economics, 34(1), 185-202.

Rigi, J. (2012). Peer production as an alternative to capitalism: a new communist horizon. Journal title Journal of Peer Production, 1(1).

Rigi, J. (2013). Peer production and marxian communism: contours of a new emerging mode of production. Capital E Class, 37(3), 397-416.

Rigi, J. (2014). The coming revolution of peer production and revolutionary cooperatives: a response to Michel Bauwens, Vasilis Kostakis and Stefan Meretz. Open Access Journal for a Global Sustainable Information Society, 12(1), 390-404.

Romano, O. (2012). How to rebuild democracy, re-thinking degrowth. Futures, 44(6), 582-589.

Schneider, F., Kallis, G., \& Martinez-Alier, J. (2010). Crisis or opportunity? economic degrowth for social equity and ecological sustainability. introduction to this special issue. Journal of Cleaner Production, 18(6), 511-518.

Sharzer, G. (2012). No local: why small-scale alternatives won't change the world. Winchester: John Hunt Publishing.

Stadler, F. (2014). Digital solidarity. Lüneburg: Mute \& PML Books.

Tanaka, M. (2001). Development of Desktop Machining Microfactory. Riken Review, 34. http://pdf.aminer.org/000/353/685/ development_of_a_micro_transfer_arm_for_a_microfactory.pdf Accessed 1.09.15.

Tapscott, D., \& Williams, A. (2006). Wikinomics: how mass collaboration changes everything. New York, NY: Portfolio..

Thomson, C. C., \& Jakubowski, M. (2012). Toward an open source civilization: (innovations case narrative: open source ecology) innovations: technology. Governance, Globalization, 7(3), 53-70.

Tocqueville, A. D. (2010). Democracy in America. New York, NY: Signet Classics.

Torvalds, L. (1999). The Linux Edge. In C. DiBona, S. Ockman, \& M. Stone (Eds.), Open sources: voices from the open source revolution (pp. 101-109). Sebastopol, CA: O’Reilly. 
Trainer, T. (2012). De-Growth: Do you Realize What it Means? Futures, 44(6), 590-599.

Troxler, P. (2011). Libraries of the peer production Era. In B. Van Abel, L. Evers, R. Klaassen, \& P. Troxler (Eds.), Open design now (pp. 86-95). Amsterdam: BIS Publishers.

von Hippel, E., \& von Krogh, G. (2003). Open source software and the private-collective innovation model: issues for organization science. Organization Science, 14, 209-223.

Walker, B., \& Salt, D. (2006). Resilience thinking: sustaining ecosystems and people in a changing world. Washington, DC: Island Press.

Walker, B. H., Abel, N., Anderies, J. M., \& Ryan, P. (2009). Resilience, adaptability, and transformability in the goulburn-broken catchment, Australia. Ecology and Society, 14(1), 12.

Wilding, N. (2011). Exploring community resilience in times of rapid change. Dunfermline: Fiery Spirits Community of Practice.

Xue, J. (2014). Is eco-village/urban village the future of a degrowth society? An urban planner's perspective. Ecological Economics, 105 , $130-138$. 